\title{
Regional development of employed persons receiving Unemployment Benefit II in Germany. An analysis of convergence across federal states
}

\author{
André Pahnke • Stefan Schneck* \\ Institut für Mittelstandsforschung Bonn, Germany
}

Received: 6 September 2013

Revised: 13 November 2013

Accepted: 18 November 2013

\begin{abstract}
In Germany, not only long-term unemployed but also employed persons are entitled to the socalled Unemployment Benefit II if the total income is below a legally binding subsistence level. Almost every third employable recipient of this means-tested benefit has actually been an employed person in 2012. Adding a regional analysis of recent developments to the existing literature, this paper concludes that German federal states generally drift apart regarding employed recipients of Unemployment Benefit II. We encourage researchers and policy makers to consider these regional differences in working poverty, which might be driven by a potentially higher social acceptance of low paid jobs in federal states with higher shares of employed Unemployment Benefit II recipients.
\end{abstract}

Keywords: $\beta$-convergence, divergence, regional development, labor market, unemployment benefits

JEL Classification Codes: J00, J30, O15

\section{Introduction}

The so-called Hartz-reforms are considered one of the major post-war reforms of the German social security system (Möller and Walwei, 2009). A very important contribution of these reforms is the combination of the former unemployment assistance ("Arbeitslosenhilfe") and social assistance ("Sozialhilfe") to the so called Unemployment Benefit II (hereafter: UBII) that was introduced in January 2005.

UBII is means-tested on the level of the so-called community in need ("Bedarfsgemeinschaft"), which is a legal concept closely related but not identical to the

\footnotetext{
* Corresponding author. E-mail: schneck@ifm-bonn.org.

Citation: Pahnke, A. and Schneck, S. (2013) Regional development of employed persons receiving Unemployment Benefit II in Germany. An analysis of convergence across federal states, Economics and Business Letters, 2(4), 182-189.
} 
household. It aims at covering basic living expenses and terminating or reducing neediness by supporting re-integration into the labor market. Basically, every individual aged 15 to 64 who is capable of working and whose household or community is in need is entitled to UBII. Hence, not only (long-term) unemployed but also employed persons might receive UBII if the total eligible income of the community is below a legally binding subsistence level. Here, we concentrate on the working individuals with incomes below this particular threshold. ${ }^{1}$

Taken as a whole, almost every third employable recipient of UBII was actually employed in 2012. From 2005 to 2008, the total number of employed UBII recipients increased from 0.86 million to 1.32 million persons. However, the latest severe economic crisis does not seem to have considerable impact on the total number of employed UBII recipients. Current figures for March 2013 show that the situation virtually has not changed since 2008. Similar to the previous years, about 1.3 million employed persons receive additional UBII-payments in Germany because of their low incomes (Bundesagentur für Arbeit, 2013).

Although this development motivated research on working poor in Germany, recent papers give some first hints that there are regional differences with respect to employed persons whose incomes are below the legally fixed subsistence level (e.g. Koller et al., 2012 or MayStrobl et al., 2011). As individuals conduct income comparisons (Hamermesh, 1965; Frank, 1984), we expect from a theoretical point of view that individuals are more likely to accept low-income jobs in regions with a high share of employed UBII recipients. The rationale for this hypothesis is that individuals are more likely to be in contact with low-income peers, which might strengthen the perception that working in low-wage jobs is kind of a social norm (Clark, 2003). The potentially higher acceptance of low wages might also attract low-wage firms. Individual as well as firm behavior might result in regional divergence with respect to employed recipients of UBII, whereas regions with initially higher shares of employed UBII recipients might experience higher growth than regions with low initial levels. Moreover, detailed knowledge about the regional developments of employed UB II recipients in Germany is generally important for policy makers in order to decide about regional labor market policy. This paper contributes an analysis of convergence across German federal states in order to conclude about the regional development of employed persons receiving UBII.

\section{Methods}

We utilize the concept of $\beta$-convergence (Baumol, 1986; Sala-i-Martin, 1996; Barro and Salai-Martin, 2003) to examine the development of employed persons receiving UBII across regions in Germany. This procedure is embedded in a neoclassical framework and relies on decreasing marginal returns. Regions that performed worse in the initial period are presumed to perform better over time than the initial rich regions. In other words, the initially poor regions should grow faster than the initially rich regions. The endogenous growth literature (Lucas, 1988) or the new geography literature (Krugman, 1991; Ottaviano and Ounga, 1998) challenge this concept and also provide explanations for divergence.

Convergence (divergence) is indicated when the regions with an initially high level of UBII recipients exhibit lower (higher) growth than the regions with initially low levels. In addition, we conduct conditional $\beta$-convergence estimates in order to check the robustness of our results. This procedure allows controlling for other factors that might drive the regional

\footnotetext{
${ }^{1}$ We do not utilize the term working poor as it is frequently applied in the context of employees with salaries lower than 60 percent of the median wage. Working poor, thus, is associated with relative poverty, while our definition applies to absolute poverty, as defined by law (Social Security Code II).
} 
development and, thus, might yield more distinct conclusions about convergence or divergence.

\section{Data}

We utilize monthly census data on the actual total number of UBII recipients provided by the German Federal Employment Agency (Bundesagentur für Arbeit). On a monthly basis, data are only available from January 2005 to September 2005 and from January 2007 onwards. For technical reasons, the Federal Employment Agency is not able to provide any data for the described gap in the time-series.

It is possible to combine this data with the Mikrozensus provided by the German Federal Statistical Office (Statistisches Bundesamt).2 This data set reveals the number of all employed persons that are at least 15 years of age and work at least one hour a week. From 2005 onwards, the Mikrozensus only provides annual averages (Statistisches Bundesamt, 2011). For this reason, the following calculations are based on annual averages for each federal state. $^{3}$ Finally, the combined data allow for an interrelation of the total number of employed UBII recipients and the total number of all employed persons for any given federal state and year.

Equation 1 shows the calculation of the change in the share of the employed in basic security for federal state $i . t_{0}$ describes the initial year of observation (2005 or 2007) while $t$ corresponds to the latest observation in year 2010 .

$$
\text { semployed }_{i, t-t_{0}}=\left(\frac{\text { employed UBII - recipients }}{\text { all employed persons }}\right)_{i, t}-\left(\frac{\text { employed UBII - recipients }}{\text { all employed persons }}\right)_{i, t_{0}}
$$

\section{Results}

Figure 1 displays the initial level of employed persons receiving UBII of all 16 federal states ${ }^{4}$ in the year 2005 and its growth between 2005 and 2010 ( $\Delta$ employed $_{i, 2010-2005}$ ). Across all 16 federal states, the average share of employed UBII recipients in 2005 was equal to 3.1 percent (see Table 1), while the average growth between 2005 and 2010 was equal to 1.4 percentage points. It becomes obvious that the federal states with low proportions of the employed in basic security (e.g., BY, BW) exhibit lower growth when compared to federal states with higher level of employed individuals receiving UBII (e.g., MV, BE). Specification (1) in Table 2 shows that the estimated slope coefficient is highly significant and positive which is in line with $\beta$-divergence across German federal states between 2005 and 2010.

\footnotetext{
${ }^{2}$ The data consist of an annual representative sample of $1 \%$ of the German population.

${ }^{3}$ As monthly data in the year 2005 are only available from January to September, we calculate the annual average with respect to this particular period.

${ }^{4}$ See Table A1 in the appendix for a list of abbreviations.
} 
Figure 1. $\beta$-divergence from 2005 to 2010

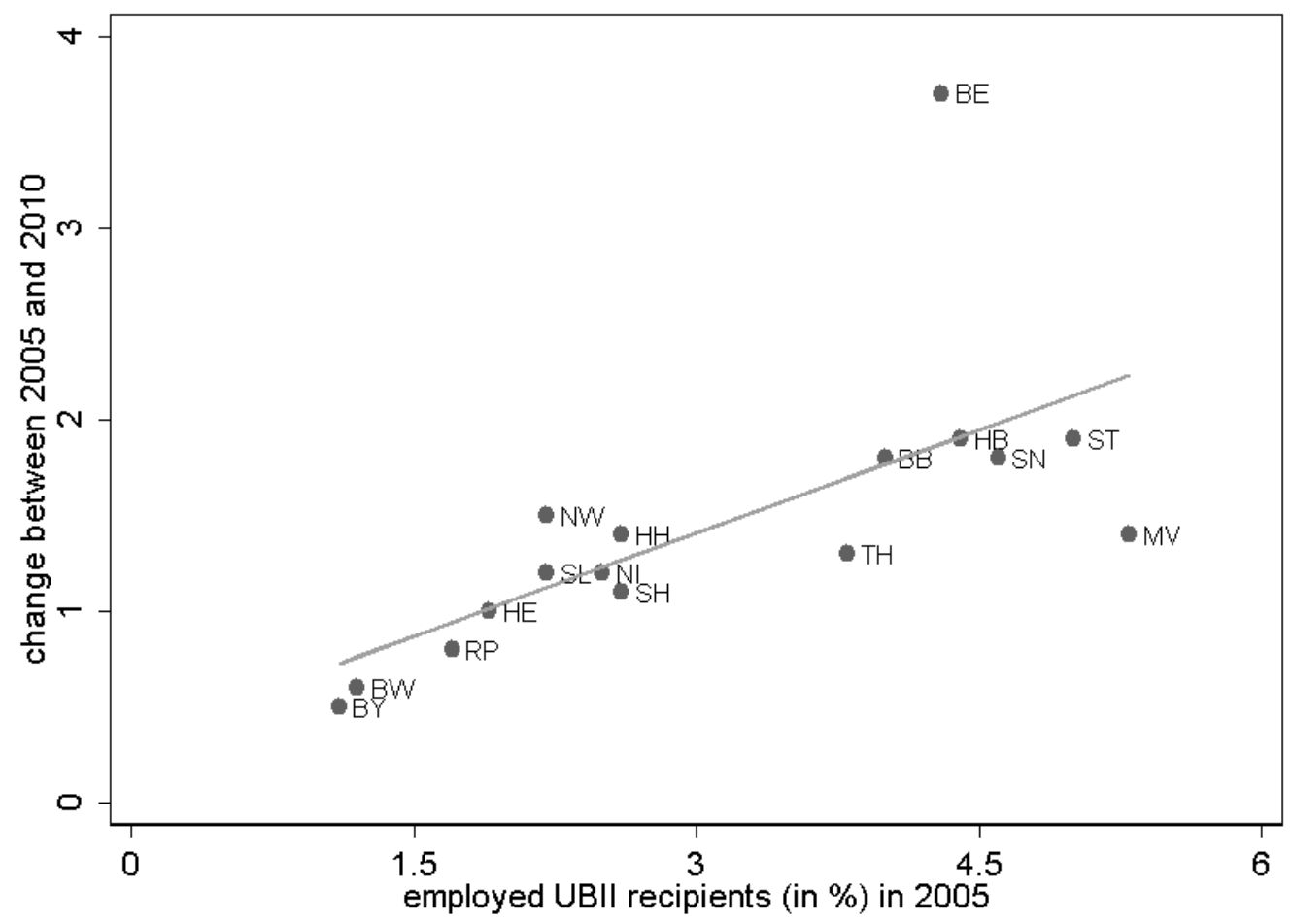

Table 1. Summary statistics for employed UBII recipients

\begin{tabular}{lcccccc}
\hline \hline & 2005 & 2006 & 2007 & 2008 & 2009 & 2010 \\
\hline \hline $\begin{array}{l}\text { Number of employed UBII recipients } \\
\text { in Germany (annual average) }\end{array}$ & 857,816 & - & $1,221,027$ & $1,323,941$ & $1,325,438$ & $1,381,382$ \\
\hline $\begin{array}{l}\text { Share of employed UBII recipients } \\
\text { i,t }\end{array}$ (in \%) & & & & & & \\
$\quad$ Mean & 3.0875 & - & 4.1625 & 4.4688 & 4.4563 & 4.5313 \\
$\quad$ Standard deviation & 1.3812 & -1.8384 & 2.0545 & 2.0113 & 1.9558 \\
\hline \hline
\end{tabular}

We also utilize monthly data on the employed UBII recipients which are available from 2007 onwards for a robustness check. Figure 2 presents the initial shares of the employed persons receiving UBII and the corresponding development between 2007 and 2010 across German federal states. 
Figure 2. $\beta$-divergence between 2007 and 2010

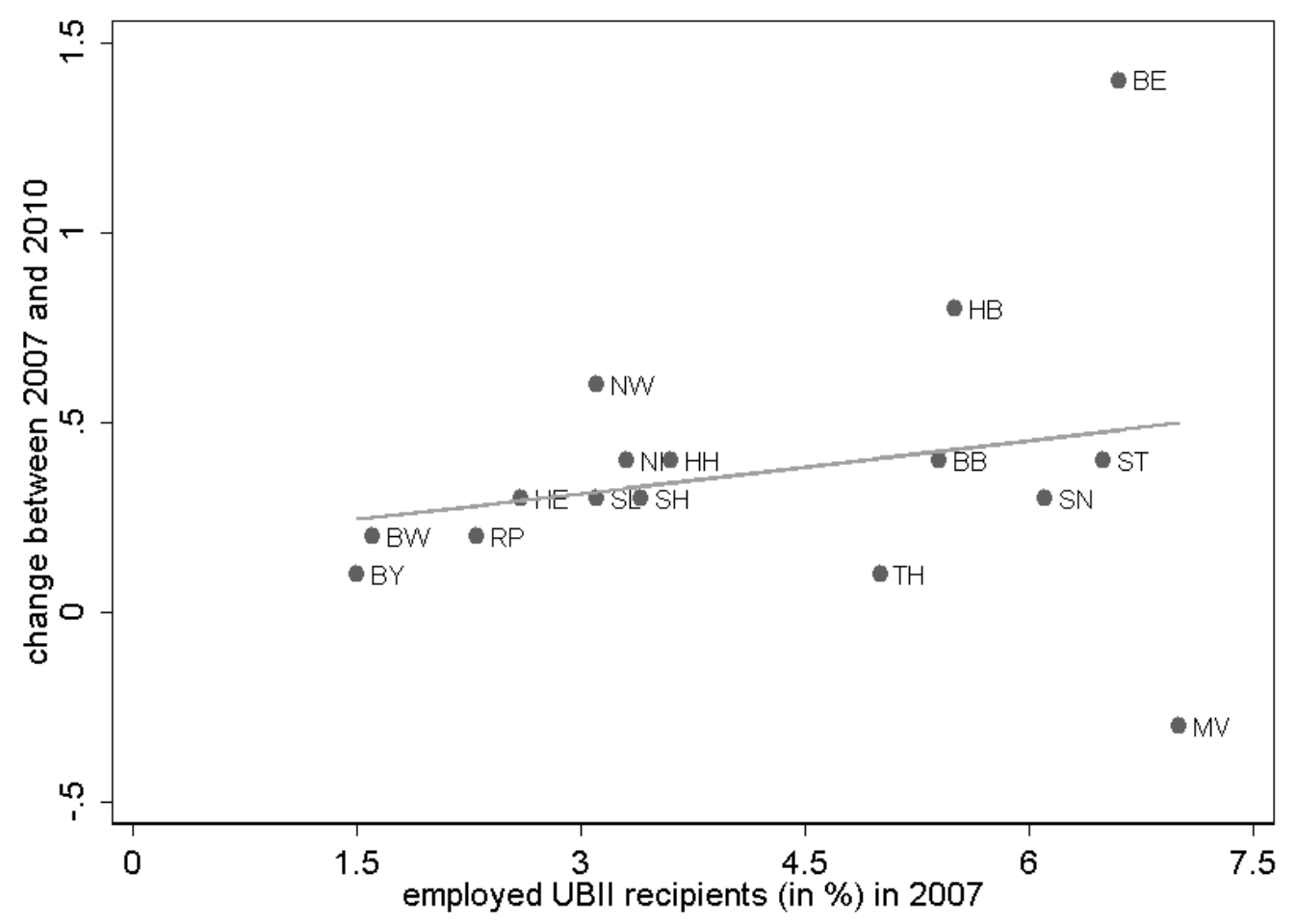

The average initial level of the employed UBII recipients was higher than in 2005 (see Table 1). We also find lower average growth which amounts to 0.4 percentage points between 2007 and 2010. Mecklenburg-Hither Pomerania (MV) is the only federal state with a decrease in the proportion of employed UBII recipients in this particular period ( -0.3 percentage points) while in all other federal states the corresponding proportion increased. Regarding $\beta$ convergence, we also estimate a positive slope coefficient which indicates divergence. According to specification (6) in Table 2, the positive slope coefficient is statistically insignificant. For this reason, $\beta$-divergence is less pronounced in the period from 2007 to 2010 when compared to the period from 2005 to 2010. This might be explained by the fact that the regional increase in employed UBII recipients was highest between 2005 and 2007 (see Table 1).

As the previous approach does not account for possible differences in economic structures across regions, we also conduct conditional $\beta$-convergence estimations. First of all, we account for structural differences between East and West Germany via inclusion of a corresponding dummy variable which equals one in case of a West German federal state. The results are presented in columns (2) and (7) of Table 2. However, the slope coefficients of the initial proportion of employed UBII recipients are still of main interest. Both coefficients are positive and statistically significant, which are further indications of $\beta$-divergence. 
Table 2. Conditional $\beta$-divergence

\begin{tabular}{|c|c|c|c|c|c|c|c|c|c|c|c|}
\hline \multirow{3}{*}{$\begin{array}{l}\text { Variables } \\
\text { Share of employed UBII recipients } s_{i, 2005}\end{array}$} & \multirow{3}{*}{$\begin{array}{c}\begin{array}{c}\text { Mean } \\
\text { (Std. Dev.) }\end{array} \\
3.0875 \\
(1.3812)\end{array}$} & (1) & $(2)$ & (3) & (4) & (5) & (6) & (7) & (8) & (9) & $(10)$ \\
\hline & & \multicolumn{5}{|c|}{$\Delta$ employed $_{\mathrm{i}, 2010-2005}$} & \multicolumn{5}{|c|}{$\Delta$ employed $_{\mathrm{i}, 2010-2007}$} \\
\hline & & $\begin{array}{c}0.358 * * * \\
(0.113)\end{array}$ & $\begin{array}{l}0.311 * * \\
(0.111)\end{array}$ & $\begin{array}{c}0.395 * * * \\
(0.127)\end{array}$ & $\begin{array}{c}0.719 * * * \\
(0.180)\end{array}$ & $\begin{array}{l}0.338^{*} \\
(0.160)\end{array}$ & & & & & \\
\hline Share of employed UBII recipients $\mathrm{s}_{\mathrm{i}, 2007}$ & $\begin{array}{c}4.1625 \\
(1.8384)\end{array}$ & & & & & & $\begin{array}{c}0.0464 \\
(0.0696)\end{array}$ & $\begin{array}{c}0.142 * \\
(0.0694)\end{array}$ & $\begin{array}{l}0.182 * * \\
(0.0828)\end{array}$ & $\begin{array}{l}0.163 * * \\
(0.0558)\end{array}$ & $\begin{array}{c}0.165 \\
(0.101)\end{array}$ \\
\hline West Germany & $\begin{array}{c}0.6250 \\
(0.5000)\end{array}$ & & $\begin{array}{l}-0.161 \\
(0.473)\end{array}$ & $\begin{array}{l}-0.0900 \\
(0.434)\end{array}$ & $\begin{array}{l}-1.539 \\
(0.912)\end{array}$ & $\begin{array}{l}0.0521 \\
(0.411)\end{array}$ & & $\begin{array}{c}0.417 * * * \\
(0.123)\end{array}$ & $\begin{array}{l}0.392 * \\
(0.187)\end{array}$ & $\begin{array}{l}-0.731 \\
(0.510)\end{array}$ & $\begin{array}{c}0.504 * * \\
(0.207)\end{array}$ \\
\hline $\mathrm{GDP}_{i, 2010^{-}} \mathrm{GDP}_{\mathrm{i}, 2005}$ & $\begin{array}{c}16,037.6250 \\
(16,175.1575)\end{array}$ & & & $\begin{array}{c}8.66 \mathrm{e}-06 \\
(7.04 \mathrm{e}-06)\end{array}$ & & & & & & & \\
\hline Unemp $_{i, 2010}$-Unemp $\mathrm{i}_{\mathrm{i}, 2005}$ & $\begin{array}{l}-4.7500 \\
(1.9037)\end{array}$ & & & & $\begin{array}{l}0.658^{*} \\
(0.312)\end{array}$ & & & & & & \\
\hline $\operatorname{Inc}_{i, 2010}-\operatorname{Inc}_{\mathrm{i}, 2005}$ & $\begin{array}{l}1,654.5000 \\
(338.8187)\end{array}$ & & & & & $\begin{array}{l}-0.000882 \\
(0.000617)\end{array}$ & & & & & \\
\hline $\mathrm{GDP}_{i, 2010}-\mathrm{GDP}_{\mathrm{i}, 2007}$ & $\begin{array}{c}4,150.0625 \\
(3,672.9630)\end{array}$ & & & & & & & & $\begin{array}{l}5.44 \mathrm{e}-05^{*} \\
(3.01 \mathrm{e}-05)\end{array}$ & & \\
\hline Unemp $_{i, 2010}$-Unemp $\mathrm{i}_{\mathrm{i}, 2007}$ & $\begin{array}{l}-1.6937 \\
(1.2572)\end{array}$ & & & & & & & & & $\begin{array}{c}0.520 * * \\
(0.204)\end{array}$ & \\
\hline $\operatorname{Inc}_{i, 2010}-\operatorname{Inc}_{\mathrm{i}, 2007}$ & $\begin{array}{l}1,002.1875 \\
(315.5918)\end{array}$ & & & & & & & & & & $\begin{array}{l}-0.000267 \\
(0.000428)\end{array}$ \\
\hline Constant & & $\begin{array}{c}0.337 \\
(0.239)\end{array}$ & $\begin{array}{c}0.584 \\
(0.656)\end{array}$ & $\begin{array}{c}0.141 \\
(0.564)\end{array}$ & $\begin{array}{l}3.313^{*} \\
(1.715)\end{array}$ & $\begin{array}{c}1.826 \\
(1.410)\end{array}$ & $\begin{array}{c}0.176 \\
(0.212)\end{array}$ & $\begin{array}{l}-0.482 * \\
(0.247)\end{array}$ & $\begin{array}{l}-0.858^{*} \\
(0.403)\end{array}$ & $\begin{array}{c}1.029 \\
(0.777)\end{array}$ & $\begin{array}{l}-0.366 \\
(0.368)\end{array}$ \\
\hline $\mathrm{R}^{2}$ & & 0.446 & 0.450 & 0.471 & 0.711 & 0.602 & 0.055 & 0.151 & 0.401 & 0.606 & 0.200 \\
\hline Observations & & & & & & 1 & 6 & & & & \\
\hline
\end{tabular}


The specifications shown in column (3) and (8) of Table 2 also control for changes in GDP in order to account for the economic development across regions. Again, the coefficients of the initial proportion of employed UBII recipients are positive and statistically significant. Our result on $\beta$-divergence is also robust to accounting for the unemployment rate on the base of the civilian active population (see specifications 4 and 9). Finally, we control for disposable income of private households per inhabitants in specifications (5) and (10). The results still advert to divergence, but for the period from 2007 to 2010 the coefficient is statistically insignificant. As further robustness checks (results not shown), we alternatively measure changes in GDP by using $\ln (\mathrm{GDP})_{2010}-\ln (\mathrm{GDP})_{\mathrm{t} 0}$ and changes in income by application of $\ln (\operatorname{Inc})_{2010}-\ln (\operatorname{Inc})_{\mathrm{t} 0}$. The coefficients of $\beta$-divergence for the time horizon from 2007 to 2010 are positive, but statistically insignificant. For period 2005 to 2010, we find significant evidence for divergence across federal states.

\section{Concluding remarks}

This paper shows that the proportion of employed UBII recipients increased in all German federal states between 2005 and 2010. Furthermore, the results indicate that growth in regions with a low initial proportion of employed individuals receiving UBII was, on average, lower than in regions with comparatively high levels in 2005. Moreover, conditional $\beta$-convergence estimations reveal robust results adverting to $\beta$-divergence for the time period from 2005 to 2010. Additional results for the time period from 2007 to 2010 are in line with divergence but the estimated coefficients are partly insignificant. Hence, $\beta$-divergence is less pronounced in the period from 2007 to 2010 in comparison to the period from 2005 to 2010.

We find that German federal states generally drift apart regarding employed recipients of UBII. Awareness of the observed divergence is important for policy makers who want to improve the situation of employed UBII recipients or reduce working poverty in Germany, respectively. It also may foster further research that explains the described development in more detail. As we take economic differences at the regional level into account, our results may also stress the importance of social conventions. Specifically, self-employed and paid employees might perceive wages below the subsistence level as a kind of social norm. In other words, it might be easier to establish employment relationships with salaries below the subsistence levels in federal states with an initially higher level of employed persons receiving UBII because of a potentially higher acceptance of such jobs in the local labor force.

Acknowledgements. We have benefited from comments by two anonymous referees.

\section{References}

Barro, R.J. and Sala-i-Martin, X. (2003) Economic growth, 2nd ed, MIT Press Books, The MIT Press.

Baumol, W.J. (1986) Productivity growth, convergence, and welfare: what the long-run data show, American Economic Review, 76(5), 1072-1085.

Bundesagentur fuer Arbeit (2013) Arbeitsmarkt in Zahlen. Erwerbstätige ALG II-Bezieher, März 2013, Nuremberg.

Clark, A.E. (2003) Unemployment as a social norm: psychological evidence from panel data, Journal of Labor Economics, 21(2), 289-322.

Frank, R.H. (1984) Interdependent preferences and the competitive wage structure, RAND Journal of Economics, 15(4), 510-520. 
Hamermesh, D.S. (1975) Interdependence in the labour market, Economica, 42(168), 420429.

Koller, L., Neder, N., Rudolph, H. and Trappmann, M. (2012) Selbststaendige in der Grundsicherung: Viel Arbeit für wenig Geld, IAB-Kurzbericht, 14/2013, Nueremberg.

Krugman, P. (1991) Increasing returns and economic geography, Journal of Political Economy, 99(3), 483-499.

Lucas, R.J. (1988) On the mechanics of economic development, Journal of Monetary Economics, 22(1), 3-42.

May-Strobl, E., Pahnke, A., Schneck, S. and Wolter, H.-J. (2011) Selbststaendige in der Grundsicherung, Working Paper 02/11, IfM-Institut für Mittelstandsforschung Bonn.

Möller, J. and Wallwei, U. (2009) Editorial, in Koch, S., Kupka, P. and Steinke, J. (eds.): Aktivierung, Erwerbstätigkeit und Teilhabe. Vier Jahre Grundsicherung für Arbeitssuchende, IAB-Bibliothek 315, Bielefeld, 11-12.

Ottaviano, G.I.P. and Puga, D. (1998) Agglomeration in the global economy: a survey of the 'New Economic Geography', The World Economy, 21(6), 707-731.

Sala-i-Martin, X. (1996) Regional cohesion: evidence and theories of regional growth and convergence, European Economic Review, 40(6), 1325-1352.

Statistisches Bundesamt (2011) Mikrozensus 2010, Fachserie 1 Reihe 4.1.1, Statistisches Bundesamt, Wiesbaden.

\section{Appendix}

Table A1. Federal states in Germany

\begin{tabular}{lc}
\hline \hline Federal state & Abbreviation \\
\hline \hline & West Germany \\
Schleswig-Holstein & \\
Hamburg & SH \\
Lower Saxony & HH \\
Bremen & NI \\
North Rhine-Westphalia & HB \\
Hesse & NW \\
Rhineland-Palatinate & HE \\
Baden-Wuerttemberg & RP \\
Bavaria & BW \\
Saarland & BY \\
& SL \\
Berlin & \\
Brandenburg & East Germany \\
Mecklenburg-Hither Pomerania & BE \\
Saxony & BB \\
Saxony-Anhalt & MV \\
Thuringia & SN \\
\hline \hline
\end{tabular}

